UDC: 378.370 .013

DOI: https://doi.org/10.24195/2414-4665-2017-8-12

\author{
Svitlana Naumkina, \\ Doctor of Political Sciences, professor, \\ Head of the Department of Political Sciences and Law, \\ South Ukrainian National Pedagogical University named after K. D. Ushynsky, \\ 26, Stariportofrankivska Str., Odesa, Ukraine,
}

Mariia Blikhar,

PhD (Candidate of Economic Sciences), associate professor, Department of Consitutional and International Law,

Lviv Polytechnic National University, 12, Bandera Str., Lviv, Ukraine

\title{
REVISITING THE ISSUE OF FUTURE TEACHERS' POLITICAL CULTURE FORMATION
}

Political culture and active social position of future teachers is of special importance because they are responsible for formation of future Ukrainian citizens, educating their national consciousness, civic culture, patriotism, tolerance, etc. The research aims to reveal the peculiarities of forming political culture of students of pedagogical specialties and the role of "Political Studies" discipline in it. The following political culture components have been distinguished: political maturity, political consciousness, political competence. The results of the carried out survey have shown that students do not have profound knowledge of the state system of Ukraine and their attitude towards political events happening is quite indifferent, which is indicative of the necessity of improving their level of political culture. The implementation of "Political studies" discipline into the curriculum of higher pedagogical institutions can help with it as it gives knowledge about the essence of political views, directions, parties, and can engage students into extracurricular activities of political focus which will obviously contribute to the development of their level of political culture.

Keywords: future teachers, political system, political maturity, political consciousness, political competence, students.

\section{Introduction}

The issue of young generation's political culture becomes especially significant in unstable periods of sociopolitical development of the country. Considering the fact that today Ukraine faces great transformations this topic is absolutely relevant and urgent.

The modern system of higher education has an important task of training graduates who should have not only high level of professionalism but mature civic position, political culture which meets modern requirements. Many state documents and regulations put forward this requirement, for instance, the Law of Ukraine "On Higher Education", National Strategy of the Development of Ukrainian Education up to 2021, the Concept of National Patriotic Education, etc.

The necessity of forming political culture, civic position of young people is covered in the works of philosophers, political experts, sociologists, lawyers, pedagogues, etc.

The state has the bright future only in case it has educated youth. The character and directions of the state policy, its stability and development depend on the level of young generation's political culture.

The concept of political culture was introduced in science by philosopher J. Haider, but it became widelyused in 50s of the last century by American political experts H. Almond, G. Powell, who defined it as "patterns of individual positions and orientations concerning policy of the participant of a certain political system, as a subjec- tive sphere making ground for political acts and providing them with the meaning" [4, p. 50]. Then this phenomenon was further investigated in the scientific work "Civic Culture" by G. Almond and S. Verba [5], where political culture is considered as a political system manifested in knowledge, feelings, assessments and intentions of the society. It was also regarded as a set of psychological orientations of people concerning political phenomena.

English researchers A. Kardiner and S. Bite emphasize the objective aspect of political culture, referring political activity and behavior to it. This idea is also supported by famous sociologist and political expert V. Kryvoshein who states that political culture is typical integral characteristics of individual or common social subject and social institutions, and the society in general, which trace the level of the development of their political consciousness, activity and behavior [3, p. 493-494].

In other words, political culture is a kind of activity of the society in terms of political relations which reflects the level of political activity and maturity of the subjects. It covers various components and levels, for example, the culture of subjects' attitude towards political authorities; culture of electoral process, culture of the formation of political and social institutions, culture of political behavior and communication, etc.

We share the opinion of S. Hrytsai who believes that there are significant contradictions between the necessity of educating politically mature youth and insufficient skills of teaching staff to make it real; between the neces- 
sity of future teachers' political culture formation and poor methodological foundations providing these components of pedagogues' professional competence [2, p. 4].

O. Vnukova states that nowadays the addressing of these challenges should be one of the main goals for our country. The formation of future university teachers' political culture is a long and complex process in which the state should act like a leading force. The "state-society" interaction as well as intercultural 'dialogue' should be the basis of university students' training [1, p. 60].

S. Hrytsai is right noting that "the high level of political culture is the main prerequisite of real democratization of the state" [2, p. 3]. It is very true that the level of people's political culture forms the political system of the state, and has a strong impact on the structure of political actors.

These challenges can be addressed only by socially mature pedagogues with flexible socio-political state of mind, stable social position, mature skills of sociopolitical activity and profound knowledge in moral, social, and political aspects of education. That is why it is so important to form and develop students' political culture as a significant component of their professional training $[2$, p. 1].

The formation of young people's political culture involves the solution of the following pedagogical tasks:

1) forming their interest in politics;

2) developing the need for political self-education;

3) contributing to mastering democratic standards and values; transforming political knowledge into stable beliefs;

4) creating favorable conditions for acquiring knowledge about political traditions and history of countries;

5) educating students' indifference, responsibility, law-obedience;

6) contributing to understanding of political freedom as human rights; lems;

7) assistance in understanding global human prob-

8 ) educating need for participating in socio-political life, etc. [1, p. 60-61].

The formation of future teachers' political culture is affected by internal and external factors.

The internal factors involve desire and need for professional self-development, understanding social role of a teaching profession, etc. They are regulated by the external ones, created by the environment. The most significant ones are those which are purposefully organized. It is about the educational process in terms of higher education because it provides an opportunity of expedient and longterm impact on the professional development of a student, the formation of his/her social position, etc. Besides, this process can be observed and controlled by the university teachers. It provides an opportunity to correct and predict further actions aimed at the formation of students' political culture [2, p. 10].

One of the significant components of future teachers' political culture is political maturity which is character- ized by political consciousness, high level of political awareness, clear and stable civic position, understanding human and civil rights, high social activeness.

Future teachers' political culture is closely connected with political competence which involves the system of motives, knowledge, skills, personal qualities which define their social maturity and help them to provide political education of schoolchildren.

The paper aims to examine future teachers' attitude towards politics and suggest the ways of improving the level of their political culture.

\section{Research methods}

In order to examine the students' knowledge of the essence of political culture in general, as well as their knowledge in the fields of political system of Ukraine, acting political parties, etc. we have designed a questionnaire consisting of 20 statements of different types (alternative questions, open-ended questions, closed questions). 365 students majoring in various fields took part in the experiment which was held at Ushynsky University.

The questionnaires were voluntarily filled in by the students during extracurricular activities.

Besides, we also conducted interviews with the experiment participants in order to examine their attitude to the "Political Studies" discipline and their interest in the political events taking place in Ukraine, which were volunteer as well. The interviewing gave the opportunity for the students to discuss the issues which were not covered by the questionnaire and to comments their answers.

\section{Research Results}

Having analyzed the questionnaire result it has been found that $78 \%$ of the respondents are proud of their origin. It means that in the years of Ukraine's independency special attention has been paid to the patriotic education and the development of national consciousness of young people. Besides, we believe that the events taking place in the east of Ukraine also play a significant role in the development of youth's attitude towards the country.

The students' replies and the carried out interviews have shown that among the governing institutions (authorities) the respondents distinguish the president of Ukraine, Verkhovna Rada, Cabinet of Ministers of Ukraine, and government (though the latter two concepts are equal). Though it should be noted that the students have no idea of what every of them is responsible for and what their duties are. During the interviews the respondents' answers were brief and unclear.

Concerning the political parties in the parliament of Ukraine, the students were undecided as well. Some of them could list some of them without indicating their leaders and main program strategies.

When the respondents were asked if they were interested in the political processes taking place in Ukraine, $49 \%$ negatively relied, and $42 \%$ indicated that they became aware of them accidently hearing some news on TV or internet or listening to their parents' talks. Only $9 \%$ of the respondents concern themselves with political events and regularly check out the recent news. It has been also 
found that $16 \%$ of the students have participated in political moves, meetings, demonstrations, and the rest of the respondents have stated that they consider these measures senseless.

Concerning the state policy, $62 \%$ believe that it should be based on democratic principles, $29 \%$ are sure that Ukraine needs an autocratic leader able to bring discipline to the country; $9 \%$ of the respondents were undecided.

When the students were asked if they would join the army to fight for the independency of Ukraine, $44 \%$ positively replied, $12 \%$ would definitely not do that, and $44 \%$ of the respondents were undecided and did not want to comment. These results are quite alarming because the absence of the desire to defend one's country is indicative of the immature civic position and indifference in the future of the state.

It should be noted that the obtained results show quite slight knowledge of the respondents about the state structure of Ukraine and rather passive attitude and indifference towards political events taking place in it.

\section{Discussion}

During the interviews we have found out that the students' attitude towards political situation in Ukraine is based on the influence of mass media and their parents' opinions. Many of them told about their disrespect and distrust of the president and government, noting that they did not fulfill promises given during their election campaign. Besides, their attitudes towards the policy and government of the country are negatively affected by the antiterrorist operation in the east of Ukraine, where some of them have lost their relatives or friends.

Thus, according to the data obtained that there is an urgent need for the formation of the students' political culture and conscious civic position.

We believe that in terms of higher education the situation can be improved by means of "Political Studies" discipline, which will help students understand the essence of political views, parties, and trends. The curriculum should touch upon the issues of political schools of thought, conceptions and directions. The implementation of the lessons should result in the students' awareness of the essence of authorities and political life of the country and world in general, as well as international political affairs; human and citizens' rights; and be able to use the acquired knowledge in their professional and social aspects of life.

\section{REFERENCES}

1. Vnukova, O. P. (2003). Formuvannia politychnoi kultury majbutnikh pedahohiv profesiino-tekhnichnykh navchalnykh zakladiv yak pedahohichna problema [Forming future teachers' political culture as a pedagogical issue]. Pedahohika i psykholohiia profesiinoi osvity Pedagogy and psychology of professional education, 1, 59-69 [in Ukrainian].

2. Hrytsai, S. M. (2009). Formuvannia politychnoi kultury maibutnioho vchytelia $\mathrm{v}$ navchalno-vykhovnomu
Besides, we suggest that the implementation of interactive teaching methods within the course of "Political Studies" will contribute to the increase of students' interest in it: for example, active discussions, seminars, roundtable discussions, role-plays, conferences, studio discussions (similar to TV ones) with the participation of famous political experts whose roles can be performed by the students themselves.

Alongside the lessons in political studies we consider it necessary to carry out purposeful work in terms of extracurricular activities with future teachers with the aim to form their political culture. For example, one can create a political club as a part of extracurricular activities, where students can use mastered knowledge and skills in designed real-life situations, as well as gain practical experience in case of organizing political education of school students.

We believe that the encouraging of students to participate in these kinds of activities will have positive impact on the development of the level of their political culture and civic position.

\section{Conclusion}

Summing up it should be noted that political culture is a significant component of general and professional culture of future teachers.

Having conducted the survey, we have found that the students' awareness of political life of their country is very low. They have no mature civic position and are not interested in political events taking place both in Ukraine and the world. Besides, they are influenced by the opinions of their relatives and mass media.

We have made a conclusion that the results obtained are quite alarming and there is an urgent necessity for addressing this challenge. We believe that it is up to university teachers to help students gain necessary knowledge and choose civic position to be conscious citizens of our country.

In our opinion, the "Political Studies" discipline implemented in the curricula of higher pedagogical institutions together with organizing extracurricular activities will have positive effect on the development of students' political culture. In our further research studies, we are going to select the most impactful teaching techniques and significant topics which should be added to the course of teaching the above mentioned subject to the students majoring in pedagogical specialties, as well as to check their efficiency.

protsesi vyshhoho pedahohichnoho navchalnoho zakladu [Forming future teachers' political culture in terms of higher pedagogical institutions]. Extended abstract of candidate's thesis. Kharkiv [in Ukrainian].

3. Kryvoshein, V. (2014). Politychna kultura [Political culture]. Navchalnyi entsyklopedychnyi slovnykdovidnyk z politolohii - Dictionary in political studies. $\mathrm{N}$. M. Khoma (Ed.). Lviv: Novyi Svit [in Ukrainian]. 
4. Almond, G., Verba, S. (1963). The Civic Culture: Political Attitudes and Democracy in Five Nations. Princeton, New Jersey : Princeton University Press [in English].

\section{ЛІТЕРАТУРА}

1.Внукова О. П. Формування політичної культури майбутніх педагогів професійно-технічних навчальних закладів як педагогічна проблема / О. П. Внукова // Педагогіка і психологія професійної освіти. - 2003. - № 1. - С. 59-69.

2.Грицай С. М. Формування політичної культури майбутнього вчителя в навчально-виховному процесі вищого педагогічного навчального закладу : автореф. дис. на здобуття наук. ступеня канд. пед. наук : спец. 13.00.04 «Теорія і методика професійної освіти» / С. М. Грицай. - Харків, 2009. - 22 с.
5. Kidwell, K. S. (2009). Politics, Performativity, Autopoiesis: Toward a Discourse Systems Theory of Political Culture. Cultural Studies. Critical Methodologies, (Vol. 9), (pp. 533-558) [in English].

3.Кривошеїн В. Політична культура // Навчальний енциклопедичний словник-довідник 3 політології / За наук. ред. Н. М. Хоми. - Львів: Новий Світ-2000, 2014. - 779 с.

4. The Civic Culture: Political Attitudes and Democracy in Five Nations. By Gabriel A. Almond and Sidney Verba. - Princeton, New Jersey : Princeton University Press, 1963. $-562 \mathrm{p}$.

5. Kidwell K. S. Politics, Performativity, Autopoiesis: Toward a Discourse Systems Theory of Political Culture / K. S. Kidwell // Cultural Studies. - Critical Methodologies. - 2009. - № 9. - P. 533-558.

Світлана Михайлівна Наумкіна, доктор політичних наук, професор, завідувач кафедри політичних наук і права, Південноукраӥнський національний педагогічний університет імені К. Д. Ушинського, вул. Старопортофранківська, 26, м. Одеса, Україна,

Марія Миронівна Бліхар, кандидат економічних наук, доиент кафедри конституційного та міжнародного права, Національний університет «Львівська політехніка», вул. С. Бандери, 12, м. Львів, Украӥна

\section{ДО ПРОБЛЕМИ ФОРМУВАННЯ ПОЛІТИЧНОЇ КУЛЬТУРИ МАЙБУТНІХ УЧИТЕЛІВ}

Актуальність дослідження зумовлена соціально-політичними змінами, що відбуваються сьогодні в нашій країні. Зважаючи на це, важливим завданням вищої школи постає формування особистості майбутніх фахівців, які не лише мають високий рівень професіоналізму, а й сформовану активну громадянську позицію, політичну культуру. Необхідність формування політичної культури, громадянської позиції особливо стосується студентів вищих педагогічних навчальних закладів, оскільки саме їм належить провідна роль у формуванні майбутніх громадян України, вихованні в них національної самосвідомості, громадянської культури, патріотизму, толерантності тощо. Метою дослідження є визначення сутності проблеми формування політичної культури і місця навчальної дисципліни «Політологія» в її формуванні, дослідження стану сформованості політичної культури майбутніх учителів. Для досягнення зазначеної мети використано загальнонаукові методи теоретичного рівня: аналіз наукової літератури, узагальнення одержаної інформації, а також методи емпіричного рівня: цілеспрямоване спостерігання, бесіди, анкетування тощо. Висвітлено підходи сучасних науковців до визначення сутності політичної культури майбутніх учителів і шляхів іiі формування у процесі професійної підготовки у вищому педагогічному навчальному закладі. Політична культура є важливою складовою професійної культури майбутніх учителів, що характеризується їхніми досягненнями в засвоєнні політичних знань, умінь, норм і традицій суспільно-політичної діяльності, які дозволяють регулювати свої політичні дії, поведінку і виступають основою готовності здійснювати громадянське виховання підростаючого покоління. Результати анкетування виявили досить поверхові знання студентів щодо державного устрою України й переважно пасивне ставлення до політичних подій, які відбуваються сьогодні в державі, що свідчить про необхідність формування їхньої політичної культури. Провідну роль у формуванні політичної культури майбутніх учителів відіграє навчальна дисципліна «Політологія», яка допомагає розібратись у сутності політичних поглядів, течій, партій, а також залучення студентів до позааудиторої роботи політичного спрямування.

Ключові слова: майбутні вчителі, політична культура, політична зрілість, політична свідомість, політична компетентність.

Reviewed by Doctor of Pedagogy, prof. T. Osypova 